\title{
The representation of mental health sufferers in administrative and legal discourse
}

Discourse \& Society 2017, Vol. 28(I) 42-59

(C) The Author(s) 2016

Reprints and permissions: sagepub.co.uk/journalsPermissions.nav DOI: $10.1 \mid 77 / 0957926516676702$ journals.sagepub.com/home/das

\section{Mariana Marchese}

National Council for Scientific and Technological Research, Argentina; University of Buenos Aires, Argentina

\section{Claudia Celerier}

University of Buenos Aires, Argentina

\begin{abstract}
This article examines the records of mental incompetence cases filed at a court of the first instance in Buenos Aires Province, Argentina. Using a Critical Discourse Analysis framework and qualitative methods, we explore the ways in which mental health sufferers are represented. Applying Tone Theory and Appraisal Theory (attitude/judgement subsystem) to our data, we distinguish two discursive zones. In one of them, subjects are constructed with linguistic resources that amount to inscribed expressions of negative social judgement on their capacity. A discursive dichotomy is created whereby people are either competent or incompetent. In the other zone, these negative dichotomous judgements are largely softened by explicitly positive ones, without disappearing altogether. We suggest that mental incompetence, far from being a dichotomous concept, might be gradual.
\end{abstract}

\section{Keywords}

Administrative/legal discourse, Critical Discourse Analysis, mental health, mental incompetence proceedings, qualitative methods

\section{Corresponding author:}

Mariana Marchese, National Council for Scientific and Technological Research of Argentina, Centro de Investigaciones en Antropología Filosófica y Cultural (CIAFIC), Federico Lacroze 2100, C.P. 1426 Ciudad Autónoma de Buenos Aires, Argentina.

Email: marianacmarch@yahoo.es 


\section{Introduction}

On the initial basis that discursive practices have a direct and concrete influence on the lives and identities of social subjects, the specific goal of this article is to study how mental health sufferers are discursively represented in legal-administrative proceedings for declaring mental incompetence. The reason for selecting this goal is that the issue of mental healthcare is, by itself, central to people's development in society. However, though there are many works that study the aforementioned issue, few of them do so from a legal point of view, a perspective that cannot be disregarded as minor if one takes into consideration that judicial discourse and its agents have the power to declare (and in so doing to classify) a person as legally incompetent, due to their mental suffering.

This specific goal is framed in a series of broader studies, the goal of which has two interrelated axes: (a) contributing to the critical understanding of the relevance of discourse in social conflicts, demonstrating at the same time the importance of applying linguisticmethodological tools to that end, and (b) providing concrete linguistic data of a qualitative nature that can help in the discussion of alternatives to solve those conflicts, especially the ones dealing with people who endure poverty and exclusion situations. In relation to (a) and (b), in particular discourses related to state institutions are analysed, as they materialise the beliefs system underpinning the action of the institutions that give shape to the state.

Like the broader research into which it is integrated, this work is based on the interpretivist paradigm; the theoretical and ideological frame from which it is produced is Critical Discourse Analysis (CDA), the methodology applied is qualitative and inductive, and for the linguistic-discursive analysis, in this case, Tone Theory and Appraisal Theory (attitude/judgement subsystem) were used. Regarding interdiscipline, which is proposed as a theoretical postulate of CDA and is not always easy to pursue throughout the concrete development of an analysis, it should be stressed that this article brings together professionals from two profoundly related disciplines: linguistics and law.

\section{Theoretical and methodological framework}

\section{Corpus}

Concerning the ethnographic context of the corpus, it should be stressed that Claudia Celerier is Judge of the First Instance Civil and Commercial Court No. 8, in the Judicial District of Quilmes, Buenos Aires Province, Argentina. The Quilmes civil and commercial tribunals were created in 1994, the same year in which Judge Celerier started her career at the District Court of Appeals. She was appointed to Court No. 8 by the Council for the Judiciary, assuming office in 2011. As the post had been vacant for over a year and temporarily filled by an acting judge, the situation was rather complex. Reorganisation took priority in different areas, such as human resources, working space and current proceedings.

She was particularly struck by the disorderly way in which mental incompetence cases were dealt with. A survey was carried out, showing a total of 271 lawsuits, most of which had been inactive for over 10 years. In total, 39 of the allegedly insane individuals had already passed away, and only those who had turned violent, run away from hospital or proved otherwise troublesome had drawn the court's attention. This state of inaction 
could also be observed in other courts, to which new judges had just been appointed: judicial involvement had only taken place when circumstances had made it absolutely unavoidable.

As dormant proceedings were re-opened and guardians were summoned to appear in court with their wards, judicial records were examined. The discourse was dark and negative, and rulings read like military statements: harsh, terse and final. Terms like 'insanity', 'the insane individual' and 'the incompetent individual' were discussed by the tribunal's professional team. In this respect we should point out that, having previously worked at the Court of Appeals, Judge Celerier had no direct experience of mental incompetence cases, nor was she familiar with the dominant discourse of first instance courts. The survey was conducted after the new 2010 Mental Health Act came into force, introducing substantial changes in the matter.

Prompted by these concerns, the judge contacted Dr Pardo's team, starting a joint inquiry and critical reflection with Dr Marchese in search of discursive alternatives, or options that might challenge the accepted model. As part of this broader project, this article focuses on the discursive representation of mental health sufferers in mental incompetence administrative/legal proceedings. Discursive practices are seen as social practices with a direct and concrete influence on people's lives and identities.

Also regarding the ethnographic context of the corpus, it should be noted that mental incompetence proceedings are aimed at protecting mental health sufferers. The Civil Code regulates people's legal capacity, as well as most of the matters pertaining to the development of individuals within society, such as identity, marital status, property relations, marriage, divorce and inheritance. It also deals with mental incompetence, which may be declared when, by reason of a mental disorder, an individual is rendered unable to manage their own person or affairs.

Before family tribunals were set up in 1997, civil courts ruled on mental incompetence and family law cases in Buenos Aires Province, as well as on many others, including bankruptcies, tort, breach of contract and damage collection claims. In this respect, it must be pointed out that civil court decisions usually refer to economic issues. Since 1994, when the Quilmes Judicial District was created, civil judges have had jurisdiction over mental incompetence proceedings, which, after the establishment of the family tribunals, has only applied to 'residual proceedings', that is, to those already filed.

In this context, the year 2010 represented a milestone, as a groundbreaking legal development took place with the passing of the National Mental Health Act, which the Buenos Aires Province agreed to enforce in its territory in 2014. Two stages may therefore be distinguished in the legal treatment of mental health sufferers. The new Act repealed a previous one and added an article to the Civil Code, according to which incompetence declarations must be grounded in interdisciplinary evaluations and are not valid for longer than three years (3rd amendment to article 152). They must specify the Acts and functions that the individual concerned is not allowed to perform, so that, as the text explicitly states, personal autonomy should be limited as little as possible.

In relation to what was stated in the previous paragraphs, it should be explained that the expression 'mental incompetence proceedings' (procesos de insania) is the one traditionally used for referring in a general way to the proceedings that make up the corpus of this research, as they were issued in the years prior to the legal reform in relation to 
which those legal proceedings were to be associated with the determination of capacities and not with the declaration of mental incompetence.

Our corpus is made up of the records of five mental incompetence cases lodged at the First Instance Civil and Commercial Court No. 8 of the Quilmes Judicial District, in Buenos Aires Province, Argentina. The persons who gave rise to the lawsuits were all poor inhabitants of that province, according to the environmental reports and interviews found in the records, a common feature we think worth noting. People of higher socioeconomic status tend to deal with these situations in ways that do not risk public exposure, a luxury low-income families cannot afford, as they need disability benefits and public health insurance in order to look after their relatives. Here is a brief outline of the cases.

M.A. Proceedings were started by M.A.'s mother when he was 21 years old, on the grounds of moderate mental retardation. M.A. also suffered from chronic heart failure and passed away after a surgical procedure to insert a prosthetic device supplied by the public health insurance providers. Although both the court and the family had played an active role in applying for it and followed the required procedure, the operation was bureaucratically delayed. M.A. attended a day care centre and had an elder sister who had suffered from depression and attempted suicide on several occasions. The record is made up of 200 leaves.

R.I. A residual schizophrenic, ${ }^{1}$ R.I. was hospitalised after violently abusing his wife and children. These domestic violence episodes took place in periods during which he either refused to take the prescribed medication or mixed it with alcohol. He was committed four times and ran away on several occasions until two doctors at one of the institutions took an interest in his case, changed his medication and helped him recover, transforming his life. According to the discharge report, the drugs he had been previously treated with prevented him from talking, thus triggering angry responses. The record has 560 leaves.

N.E. N.E. is a residual schizophrenic who was hospitalised several times. In 2003 he attempted suicide, being last institutionalised in 2005. The lawsuit was filed by his mother, with whom he lived, his father having passed away. In 2013, he was interviewed in court, stating that he used to watch television, had a girlfriend, took care of himself, had friends in the neighbourhood, took his medication and felt very well as a result. According to the medical report, in stable periods he has the capacity to carry out simple and complex acts of disposal, get married, take part in legal proceedings, follow therapeutic instructions and give his informed consent to the administration of medication. The record consists of 206 sheets.

J.J. At the time the case was brought to court, J.J. was 24 years old, having suffered from simple schizophrenia since he was 14 . He was hospitalised at his parents' request. Neither he nor his mother, who was appointed guardian, has appeared before the tribunal since the new judge took over, though she acknowledged receipt of the latest summons by signing the legal form. Further attempts are presently being made to obtain their attendance. In this respect it should be pointed out that the summons procedure is very complex, as often in disadvantaged areas house number signs are missing or cannot be made out. Sometimes police assistance is required, which naturally tends to cause alarm. According to the 1997 environmental report, J.J.'s socioeconomic status was low; he had 
no telephone or health insurance. It is also stated that he was provided with adequate care and the requirements of his situation were met. The record has 184 sheets.

M.P. M.P.'s schizophrenia became apparent when he was 20 years old. When he was 24 , his mother started mental incompetence proceedings, legally represented by a private lawyer assigned by the Buenos Aires Bar Association, who has been in charge of the case ever since. M.P. attended secondary school up to the fourth year and graduated as a sales assistant. He lives with his parents and three siblings. Twice hospitalised, he continued treatment as an outpatient, the family group having been judged capable of providing emotional containment. He attends a sheltered workshop twice a week and hands out plumbers' leaflets in his spare time. The record consists of 444 sheets.

Regarding the linguistic materiality of the corpus, we follow De Miguel (2000) and González Salgado (2009), in whose view legal/administrative language encompasses administrative, legal and judicial texts. Two issues must be briefly addressed before we proceed. First, even though these texts use similar linguistic resources, frequencies and co-occurrences would need to be checked in each case to determine whether they coincide (Pardo, 1996). Second, the social action fields (Wodak, 2000, 2003) of such texts do not exactly correspond: legal discourse, for example, belongs to the field of law-making or norm production, whereas judicial discourse arises from the process whereby the law is applied by legal professionals. Administrative discourse, however, involves a wide variety of practices (notes, reports, rulings, memoranda and circular letters, among others) that take place in different fields.

The legal/administrative discourse of mental incompetence proceedings materialises through records, that is, sets of chronologically arranged texts containing the discourse of those who take part in them. The chief discursive participants are the following: the expert witnesses who examine the allegedly insane and write reports; the witnesses, who give evidence about their situation; family members; and judges. As in other legal procedures, discursive productions may be mediated: witnesses, for instance, testify orally, but their deposition is taken down by court officials.

In relation to the nature of judicial language and from the point of view of legal theory, Ross (1959) states that the emotive function of language is not limited to those expressions that lack descriptive meaning, since many words have at the same time descriptive meaning and emotional charge. This idea is particularly important for judicial discourse because it opens the way for persuasion, insinuated under the guise of an apparently rational and neutral argumentation.

In a similar line of thought and also from legal theory, Alexy (1989) understands judicial discourse as a linguistic activity that is a part of general practical discourse, but that is limited by the need to rationally ground the argumentation with the current legal system. In this sense, the process of argumentation is temporally limited and regulated by rules of procedure. The author explains that, despite this limitation, the application of the law should not end at subsumption (application of a general principle to a particular case), because this application demands the applier's evaluations, and these evaluations have central importance at the moment of making and grounding decisions.

Also calling into question the concepts of neutrality and objectivity and critically revising the presuppositions connected to judicial discourse, Collantes Fraile (2005) asserts that there has been a strong current of thought according to which this discourse 
was defined in terms of the establishment of abstract, total and absolute dichotomies and taking for granted that the legal system could make neutral and objective decisions based on those dichotomies. Although, according to this author, this vision lead to a crisis that revealed those criteria as obsolete and cleared the path for new directions in legal studies, the research we have decanted into this work shows that part of that vision is still current in judicial practices.

\section{Tone Theory and Appraisal Theory: Two complementary perspectives}

CDA provides the theoretical framework for this study, both in its European (Fairclough, 1992; Van Dijk, 1993; Wodak, 2000) and Latin American (García da Silva, 2007; Montecino, 2010; Pardo, 2008, 2011; Pardo Abril, 2007; Resende and Ramalho, 2006) varieties. Qualitative and inductive linguistic analysis methods have been applied (Pardo, 2011), within an interpretive paradigm (Guba and Lincoln, 1998).

In relation to CDA as a frame, it is also noted that researchers from different countries have positioned themselves in it to reflect on various issues related to mental health. Some of the analysed issues are mental health, violence and social policies (Paterson and Stark, 2001); mental health and recovery treatments (Mancini, 2011; Mancini and Rogers, 2007); mental health, poverty and cognition (Pardo and Buscaglia, 2008); mental health, social change and bioethics discourse (Pinho, 2009); and mental health, psychiatric discourse and discourse analysis applications (De Pinho et al., 2009). Within this group, the work we present here deals specifically with the issues of mental health and legal proceedings for declaring mental incompetence.

For linguistically orientated discourse analysis we have drawn on Appraisal Theory and Tone Theory, which we see as complementary (Marchese, 2009; Pardo, 2010). The former enabled us to consider the linguistic expression of judgements (attitude system) (Kaplan, 2004; White, 1999) in order to describe and account for the semantic choice systems through which evaluations are made, stances are taken and textual subjects are constructed. The latter (Pardo, 2011) allowed us to examine the way in which reinforcing and qualifying resources were distributed, so that we might describe and explain the speaker's point of view on the issues discussed.

The use of these twin methodological tools has proved fruitful in previous research (Marchese, 2009, 2010) because of their shared foundations. In the first place, both regard discourse as a major component of social practices. Second, both focus on the linguistic resources that play a role in the negotiation and naturalisation of ideological positions. Rooted in Systemic Functional Linguistics, Appraisal Theory deepens the analysis of the interpersonal function to explore the ways in which ideological views are discursively made to appear 'natural' (Kaplan, 2004). Tone Theory, however, accounts for the ways in which linguistic resources are deployed to play down or reinforce discursive information, producing linguistic evidence of the speakers' ideological stand on the points they wish to communicate.

According to Pardo (2010), Appraisal Theory centres on the lexical and grammatical aspects of texts, whereas Tone Theory looks also into the ways in which syntax constructs meaning. In this respect, it should be pointed out that the former includes a graduation subsystem that White (1999) conceives as a scaling dimension running through the whole appraisal system. However, as the ways in which scaling manifests 
itself are not always universal, and the description available to us is valid for Spanish, we think it would be useful to confine our analysis to the reinforcing and downtoning resources of this language (Lavandera, 1985; Pardo, 1996, 2011).

\section{Analysis}

\section{From dichotomy to gradualness: Two discursive zones}

Our linguistic analysis of the mental incompetence case records reveals the existence of two discursive zones. The first roughly coincides with the texts produced before 2011, in which by and large the representation of mental health sufferers is constructed by inscribing negative social esteem judgements on their competence/capacity. The linguistic resources used in this construction appear repeatedly on the textual surface, constituting unmarked or prevalent features. Following White (1999), we sum this up in Table 1.

In this zone, the discursive representation of mental health sufferers is thus linked to their capacity/competence: the person at the centre of the proceedings is either competent or incompetent. For this reason we call it the discursive dichotomy zone (Table 2), understanding dichotomy as 'a division or contrast between two things that are or are represented as being opposed or entirely different' (Oxford Dictionary, n.d.).

By contrast, corpus analysis has shown the existence of a second discursive zone, where the dichotomy has been largely softened, even though inscribed negative social esteem judgements have not disappeared. This description would apply to the texts written since 2011, in which mental health sufferers' incompetence/competence is not viewed as an 'all-or-nothing' but rather as a gradual issue. Hence, it has been called the discursive gradualness zone, as can be seen in Table 3.

Table I. Inscribed negative social esteem judgements on individuals' competence/capacity.

\begin{tabular}{lll}
\hline $\begin{array}{l}\text { Inscribed judgement: } \\
\text { social esteem }\end{array}$ & Negative & Positive \\
\hline $\begin{array}{l}\text { Is the individual } \\
\text { competent/capable? }\end{array}$ & $\begin{array}{l}\text { Linguistic resources used in } \\
\text { this construction: unmarked } \\
\text { (dominant) features }\end{array}$ & $\begin{array}{l}\text { Linguistic resources used in this } \\
\text { construction: marked features }\end{array}$ \\
\hline
\end{tabular}

Table 2. Discursive dichotomy zone.

Dichotomous construction of mental suffering

\begin{tabular}{ll}
$\begin{array}{l}\text { Incapacity/incompetence } \\
\text { (unmarked feature) }\end{array}$ & $\begin{array}{l}\text { Capacity/competence } \\
\text { (marked feature) }\end{array}$ \\
\hline
\end{tabular}

Table 3. Discursive gradualness zone.

Gradual construction of mental suffering 


\section{First zone: Discursive dichotomy}

The following are typical examples of the linguistic resources prevalent in this zone. The case, leaf and discourse participants (expert witness, witness, family member and judge) are enclosed in brackets.

The use of prefixes indicates absence and diminutive suffixes (in bold and underscored) to express physical disability, inadequate social skills or difficulty in socialising:

Example 1. To make the above situation worse, the fact that he suffers from advanced cardiac insufficiency ... (M.A., leaf 17 , family member)

[Agravando la situación anteriormente descripta, el hecho de padecer una avanzada insuficiencia cardiológica ...]

Example 2. [He] is a mentally disabled boy ... (M.A., leaf 46, witness)

[... es un chico con discapacidad mental ...]

Example 3. ... the boy is unemployed due to disability ... (M.A., leaf 46, witness)

[... el chico es desocupado por la incapacidad ...]

Example 4. She gets by on what she makes for herself and her son, who is a little invalid. (N.E., leaf 45, witness)

[Sobrevive con lo que gana, para ella y para el hijo que es enfermito.]

Example 5.... unfavourable prognosis ... (N.E., leaf 85, judge)

[... pronóstico desfavorable ...]

Example 6. ... the son is disabled ... (M.P., leaf 19, witness)

[... el hijo es discapacitado ...]

Example 7. Particulars of the insane individual. (M.P., leaf 108, expert witness)

[Datos del insano.]

The following examples show nouns and adjectives/adjective phrases ${ }^{2}$ referring to or reinforcing the idea of inadequate social skills or difficulty in socialising (in bold and underscored):

Example $8 . .$. to develop into symptoms of mental weakness ... (M.A., leaf 17, family member) [... hasta derivar en un cuadro de debilidad mental ...]

Example 9. I was given various diagnoses, most of which coincided and revealed severe personality disorders ... (M.A., leaf 17, family member)

[... se me dieron diversos diagnósticos, siendo la mayoría de ellos coincidentes y develadores de graves trastornos de personalidad ...]

Example 10. [He] is a bit gone in the head ... (M.A., leaf 46, witness)

[... es un chico $\underline{\text { ido }}$....

Example $11 . .$. the person that has given rise to these proceedings ... suffers from paranoid schizophrenia ... (M.P., leaf 9, expert witness)

[... el causante de autos ... padece de Esquizofrenia Paranoide ...]

Example 12. ... you can see he is sick ... (M.P., leaf 25, witness)

[... se nota que está enfermo ...] 
The use of the negative adjective 'no', negative adverb 'not' and intensifying adverb 'even' 3 refers to and reinforces the idea of inadequate social skills or difficulty in socialising. In example 13, negation co-occurs with linguistic resources already described, for instance the use of prefixes indicating absence or adjectives/adverbs that stress the idea of diminished social competence. ${ }^{4}$ All these resources are printed in bold and underscored:

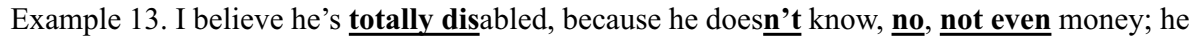
doesn't know how to run errands. (M.A., leaf 46, witness)

[... creo que es discapacitado total, porque no conoce no ni el dinero, no sabe hacer mandados.]

Example 14. [He] has no friends ... (M.A., leaves 46 and 47, witness)

$[\ldots \underline{\text { no }}$ tiene amigos ...]

Example 15. He does not have a clear perception. (M.A., leaf 54, expert witness)

[... su percepción no es clara ...]

Example 16.... not having learned to read and write or the ability to perform simple arithmetic operations, and, therefore, money calculations. (M.A., leaf 54, expert witness)

[... no habiendo adquirido la lectoescritura ni la posibilidad de operar con funciones matemáticas sencillas y por ende con el dinero.]

Example 17. [He] has nothing and doesn't work. (J.J., leaf 19, witness)

[No tiene nada y no trabaja.]

Example 18. [He] is a boy that can't provide for himself ... (M.P., leaf 25, witness)

[... es un chico, que no se mantiene solo ...]

Example 19. His behaviour is apathetic; he does not work or engage in any social activity. (N.E., leaf 64, expert witness)

[... su conducta es apática, no trabaja, ni tiene actividad social.]

It should be noted that, in example 13, the Spanish coordinating conjunction 'ni' means 'not even' - it is not employed as an additive coordinator, but to suggest an extreme or unlikely case.

The use of the Latin expression prima facie (at first sight) refers to and stresses the idea of inadequate social skills or difficulty in socialising. Again linguistic resources co-occur, as the phrase co-exists in close proximity with nouns and adjectives that reinforce the notion, as well as with prefixes indicating absence, all of which are highlighted in bold type and underscored:

Example 20.... it has been prima facie proved that the person that has given rise to these proceedings suffers from residual schizophrenia, which makes it impossible for him to work. (N.E., leaf 85 , judge)

[... se acredita prima facie que el causante padece de esquizofrenia residual, lo que lo imposibilita para realizar trabajo alguno.]

Example 21... it has been prima facie proved that the person that has given rise to these proceedings suffers from mental weakness, which makes it impossible for him to ... (M.A., leaf 95 , judge)

[... se acredita prima facie que el causante padece $\underline{\text { debilidad mental }}$, lo que lo imposibilita ... ] 
Example 22. ... it has been prima facie proved that the person that has given rise to these proceedings suffers from residual schizophrenia, which makes it impossible for him to work. (R.I., leaf 133, judge)

[... se acredita prima facie que el causante padece de esquizofrenia residual, lo que lo imposibilita para realizar trabajo alguno.]

Example 23. ... it has been prima facie proved that the person that has given rise to these proceedings suffers from schizophrenia ... which makes it impossible for him to work. (J.J., leaf 155 , judge)

[... se acredita prima facie que el causante padece de esquizofrenia... lo que lo imposibilita para realizar trabajo alguno.]

Considering the discursive context described and summed up in Table 4, it is hardly surprising that mental health sufferers should be assigned a passive role. This is shown in the use of objective/possessive pronouns, ${ }^{5}$ as can be seen in Table 5 .

Table 4. Discursive context.

a little invalid

mentally disabled

unemployed due to disability

gone in the head

totally disabled

does not work or engage in any social activity

it has been prima facie proved that the person that has given rise to these proceedings

suffers from residual schizophrenia, which makes it impossible for him to work

Table 5. Objective/possessive pronouns.

Example 24. [S/he] looks after him

[lo cuida]

Example 25. [S/he] takes care of him

[lo atiende]

Example 26. [S/he] washes his clothes

[le lava la ropa]

Example 27. has to cook for him

[le tiene que cocinar]

Example 28. [S/he] gives him his medicines and buys them

[le da y le compra los remedios]

Example 29. [S/he] takes him

[lo lleva]

Example 30. [S/he] brings him

[lo trae]

Example 31. [They] keep him neat and clean, take him to the doctor, feed him

[lo tienen bien ordenadito, limpio, lo llevan al médico, lo alimentan] 
Since this discursive construction of mental health sufferers is dominated by a negative view, the linguistic resources through which positive judgements are materialised will appear as marked features. The adjective 'coherent' in example 32, for instance, stands out as different (i.e. marked) from the linguistic resources described previously. In terms of information hierarchy, however, this positive feature is placed in the zone of lower communicative dynamism (Firbas, 1966) of the rheme, which starts with the verb 'is'. As the rheme progresses, the adversative connector 'but' tones down the meaning of the adjective in the first part and reinforces the information provided in the second: 'the use of concrete and puerile language prevails'. 'Concrete and puerile language' constitute, in fact, the focus of the utterance:

Example 32. The course of his thought is coherent, but the use of concrete and puerile language prevails. (M.A., leaf 54, expert witness)

[El curso de su pensamiento es coherente pero se destaca la utilización de terminología concreta y pueril.]

\section{Second zone: Discursive gradualness}

The following examples are representative of the linguistic resources found in the second discursive zone of the corpus. Inscribed negative social esteem judgements on individuals' mental capacity/competence have not disappeared, but the dichotomy has been mitigated. Capacity/competence is conceived as more gradual. After each example we indicate the case record to which it belongs, the leaf and the discursive participant responsible for the utterance: expert witness, judge, witness or family member.

The use of prefixes indicates the absence to express inadequate social skills or difficulty in socialising (in bold type and underscored):

Example 33... let Mrs CNC, parent of the insane individual in these proceedings, be summoned ... (J.J., leaf 174, judge)

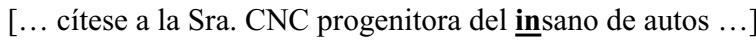

Example 34. Let this report be added to the record, [and] taken into account, and, in view of what has been reported, let the file be handed over to the District Counsel for the Incompetent to that end. (M.A., leaf 136, judge)

[Agréguese, téngase presente y en atención a lo informado pasen los presentes obrados a la Asesoría de Incapaces departamental, a sus efectos.]

Example 35. ... a ruling has been passed, declaring the person that gave rise to the proceedings incompetent. (N.E., leaf 188, judge)

[... se ha dictado sentencia, declarando incapaz al causante ...]

Adjectives, verbs and adverbs/adverbial constructions refer to the individual's potential (in bold and underscored):

Example 36. [he] is in a good state of health, states that he gets on very well with his sister and mother, [as well as] with his friends, and that he is glad to attend the specialised centre every day. (M.A., leaf 118 , judge) 
[... presenta un buen estado de salud general, manifiesta llevarse muy bien con su hermana y su madre, con sus amigos y que está contento de concurrir al centro especializado todos los días.]

Example 37. The person that gave rise to these proceedings is awake, lucid. (R.I., leaf 382 , expert witness)

[El causante se encuentra, vigil, lúcido.]

Example 38. [we] have held a fluent conversation in front of his brother and permanent guardian, which has persuaded me of Mr X's improvement ... (R.I., leaf 555, judge)

[... hemos mantenido un fluido diálogo en presencia de su hermano y curador definitivo, que me persuaden de la mejoría del Sr. XX ...]

Example 39. The person that gave rise to these proceedings answers coherently the questions that are put to him. (N.E., leaves 168 and 198, expert witness)

[El causante responde con coherencia a las preguntas que se le formulan.]

Example 40. [He] is active and very talkative. (N.E., leaf 168, expert witness)

[Es activo y muy conversador.]

Example 41. The person examined is lucid, self- and allopsychically orientated. (M.P., leaf 156, expert witness)

[El examinado se presenta lúcido, orientado auto y alopsíquicamente.]

Example 42. Currently, some days he helps his father by performing simple tasks; $\underline{\text { other days }}$ he does not, feeling unwell or tired. (M.P., leaf 191, expert witness)

[Actualmente, algunos días colabora con su padre en tareas simples; otros días no por malestar o cansancio.]

Example 43. I recommend he should carry out work activities at an institution that specialises in the pathology he suffers from ... at least four times a week (M.P., leaf 191, expert witness) [... se recomienda que realice actividades laborales en instituciones especializadas para la patología que padece ... con una frecuencia semanal de al menos cuatro veces semanales.]

Example 44. A conversation is held with the person giving rise to these proceedings ... he $\underline{\text { states }}$ that he likes the life he leads very much; he says he attends a sheltered workshop on weekdays from 9 to 12 a.m., where he works in various crafts; he adds that he has a very good emotional bond with his whole family. (M.P., leaf 194, expert witness)

[Se dialoga con el causante ... el mismo refiere encontrarse muy a gusto con la vida que desarrolla; comenta que concurre durante la semana de 9 a 12 hs a un taller protegido en el que realiza diversos trabajos artesanales, agrega tener una muy buena relación afectiva con toda su familia.]

Example 45. He states that ... he helps his father by performing simple tasks when he can and that he attends a sheltered workshop for two hours and a half twice a week, and that he has graduated as a sales assistant; that in his spare time he hands out plumbers' leaflets. (M.P., leaf 311, judge)

[Manifiesta que ... colabora con su padre en tareas simples cuando puede y que concurre a un taller protegido 2 veces por semana 2 horas y media y que se recibió de auxiliar en ventas, que en sus tiempos libres hace repartos de tarjetas de plomería.] 
Certain linguistic aspects of these examples are worth dwelling on. First, if we compare the object of the phrasal verb 'get on with', that is, 'his friends' in example 36, with 'has no friends' (example 14) in the first discursive zone of M.A.'s file, we may well wonder when he started going to the day care centre. We know from the case record that he had been attending it by the time the latter text was written, and yet the circumstance is not mentioned in the witness' statement.

Second, the verbs 'states' (examples 36, 44 and 45), 'answers' (example 39), 'says' and 'adds' (example 44) indicate verbal processes, placing the subjects in the role of speakers (Halliday and Matthiessen, 2004). The references to mental sufferers' discourse in the first zone, by contrast, are negative and aimed at characterising the discourse itself - as in 'the use of concrete and puerile language prevails' (example 32). The importance of the difference lies in the fact that discursive roles both construct and reflect the distribution of social roles, accounting for the parts played by social actors in certain scenarios.

Third, and similarly, we should notice the use of the first person plural in example 38 ('[we] have held a fluent conversation'), which does not appear in the first zone.

We might therefore conclude from this analysis that, in this zone, mental health sufferers are voiceless, whereas in the second, their voices are beginning to be heard. Even though asymmetry is an element that plays a role in the communicative relation between subjects with mental suffering and the professionals that interact with them (even more so when this relation takes place in an institutional context) (Bonnin, 2014a), in the same line as Broer et al. (2014), we understand that the described communicative situation is relevant because it manifests that, in the frame of legal proceedings related to mental health, the subjects' participation is becoming a goal in order to enhance the quality of mental health care.

In the following are nouns that refer to the individual's potential, co-occurring with interrogative adjectives introducing questions about it (in bold type and underscored):

Example 46... let the medical and psychiatric report added to this file be updated, specifying the scope of the functions and acts that the person giving rise to these proceedings is not fully able to perform, what acts he may carry out for himself, and for which the guardian's assistance is required (3rd amendment to article 152 of the Civil Code). (M.A., leaf 138, judge)

[... se lleve a cabo la actualización de la pericia médico psiquiátrica glosada en autos, especificando los facultativos el alcance de las funciones y actos para los cuales se encuentra limitado el causante, qué actos puede realizar por sí y cuáles con asistencia de curador (art.152 ter. del Código Civil).]

Example $47 . .$. let the medical and psychiatric report added to this file be updated ... specifying the scope of the functions and acts that the person giving rise to these proceedings is not fully able to perform, what acts he may carry out for himself, and for which the guardian's assistance is required ( $3 \mathrm{rd}$ amendment to article 152 of the Civil Code). (M.P., leaf 188 , judge)

[... se lleve a cabo la actualización de la pericia médico psiquiátrica glosada en autos ... especificando los facultativos el alcance de las funciones y actos para los cuales se encuentra limitado el causante, qué actos puede realizar por sí y cuáles con asistencia de curador (art.152 ter. del Código Civil).] 
Example 48. ... in order to fulfil the requirements for the interdisciplinary report ... specifying the scope of the functions and acts that the person giving rise to these proceedings is not fully able to perform, what acts he may carry out for himself, and for which the guardian's assistance is required ... (N.E., leaf 189, judge)

[... a los fines de cumplir los requisitos del informe interdisciplinario, especificando los facultativos el alcance de las funciones y actos para los cuales se encuentra limitado el causante, qué actos puede realizar por sí y cuáles con asistencia de curador ...]

In this context, it is worth noting that among the meanings of the Spanish word 'alcance', which has been rendered as 'scope', is 'the capacity, physical, intellectual, or otherwise, that enables someone to realise, approach, or access something' (Real Academia Española, 2001). ${ }^{6}$

\section{Conclusion}

Corpus analysis has yielded linguistic evidence of a developing shift in the way in which the discursive representation of mental health sufferers is constructed. The notion of competence/incompetence is moving beyond the dichotomy sane/insane towards a more gradual approach. Two discursive zones have been identified in this respect, of which examples have been provided.

In the discursive dichotomy zone, an 'all-or-nothing' view is taken. This is expressed, for instance, through prefixes indicating absence ( $i n, d i s, u n)$, the negative adjective $n o$, the negative adverb not, the intensifying adverb even, ${ }^{7}$ nouns and adjectives reinforcing the idea of incompetence ('mental weakness', 'severe disorders') and the co-occurrence of these resources ('totally disabled'). ${ }^{8}$ Negative judgements can still be found in the discursive gradualness zone, but the black-and-white distinction is mitigated. This is achieved, for example, by deploying adjectives and adverbs that stress the individual's potential ('answers coherently'; 'very talkative') as well as interrogative adjectives that introduce questions about it ('what acts he may carry out for himself, and for which the guardian's assistance is required'). In this second zone, mental health sufferers' voice can be heard ('he states'; '[we] have held a fluent conversation'). These discursive zones correspond to two different legal frameworks, the passing of the 2010 Mental Health Act marking the turning point.

Despite the new legislation, however, the dominant legal/administrative discourse, that is, that which sets the norm, is one of dichotomy. Thus, mental incompetence proceedings are still called 'insanity cases' and the individuals that give rise to them are labelled 'insane' or 'incompetent' in informal talk. The new Civil and Commercial Code, which came into force in August 2015, just as we were finishing our investigation, reaffirms the paradigm shift. It was among the first to follow the principles set out in the United Nations Convention on the Rights of Persons with Disabilities, which had already been incorporated into Argentine domestic law. The change in concept and terminology must be greeted with approval as a discursive transformation aimed at altering current social representations, and therefore the ways in which we understand the world and people's roles in it.

In the context of these incipient developments, we believe active intervention is required, since modifying the rigid legal/administrative system is not an easy task. In fact, the use of the terms 'insane' and 'insanity' shows how deeply mental models are 
rooted in the dichotomous representation and how naturalised the latter has become. Nevertheless, this article provides linguistic evidence of the transformation of dominant discourse, that is, of the reference system whereby signs are given meaning at a certain point in history (Raiter, 1999), a process that is currently underway.

This, we think, is the path to take, though we may not always keep to it as our mental models are also influenced by what has been thus far the dominant discourse. Our goal is to collaborate in the modification of socio-discursive representations, which entails leaving behind the concept of 'mental incompetence' and going towards the idea of 'determination of capacities' or, in other words, decentralising lack and focalising capacity. Court rulings should not enforce the social exclusion of individuals, but rather their protection and inclusion.

Success in this joint endeavour to look for alternatives will demand the critical reflection of legal and health professionals, social workers and researchers committed to social transformation, since, as explained by Casstevens (2010) and Essen et al. (2015), the biomedical model is the one that has predominated in the area of mental health, pervading all discourses associated with it and not facilitating the relation between disciplines, an indispensable element in the context of mental health (Cox, 2009; Hausner et al., 2007).

In short, we believe that, in fact, the analysis we have realised has two underlying features: on the one hand, the movement from a paradigm, the biomedical model (eminently dichotomous and based mainly on the individual plane), towards the search for other approaches (Bonnin, 2014b; Donnelly and Long, 2003; Jhangiani and Vadeboncoeur, 2010; Petersen, 1998), and on the other hand, how this movement also has an impact on the judicial practices associated with mental health.

Finally, we must not let the formalities and requirements of legal/administrative or academic discourse obscure the fact that it is people's lives that are at stake in these cases. In this spirit, we would like to dedicate this article to M.A., whose real name was Mario and whose identity and potential, despite the efforts of his family and many of the professionals that took part in the proceedings, fell through the cracks of institutional bureaucracy.

\section{Acknowledgement}

The authors would like to thank Monica Descalzi, who translated this paper into English.

\section{Declaration of conflicting interests}

The author(s) declared no potential conflicts of interest with respect to the research, authorship, and/or publication of this article.

\section{Funding}

The author(s) received no financial support for the research, authorship and/or publication of this article.

\section{Notes}

1. By and large, schizophrenia makes it difficult to distinguish what is real from what is not, think clearly or act socially in a normal way. In residual schizophrenia cases, some of these 
symptoms remain, but without any obvious hallucinations or signs of mental incoherence. A schizophrenic episode has taken place in the past, but no major symptoms can be detected during the psychiatric evaluation. Not every manifestly schizophrenic patient will later suffer from residual schizophrenia.

2. Translator's note: The adjective 'ido' in example 10 has been rendered as 'gone in the head'. 'Ido' is the past participle of the verb 'ir', which means to go.

3. Translator's note: In the Spanish text, the speaker employs the negative adverb 'no' and the coordinating conjunction 'ni'.

4. Translator's note: The Spanish 'discapacitado total' (noun+adjective) has been rendered as 'totally disabled', the adverb 'totally' stressing the idea of diminished competence in English.

5. Translator's note: The original text contains only objective pronouns. 'Le (objective pronoun) lava la ropa' has been rendered as '[S/he] washes his (possessive pronoun) clothes'. [S/he] has been used for unspecified singular third-person subjects.

6. Translator's note: In these examples, the meaning of the word roughly coincides with the first sense of 'scope': 'The extent of the area or subject matter that something deals with or to which it is relevant'. The second sense of 'scope' would be more similar to the Spanish definition mentioned in the text: 'The opportunity or possibility to do or deal with something' (Oxford Dictionary, n.d.).

7. See Note 3.

8. See Note 4.

\section{References}

Alexy R (1989) A Theory of Legal Argumentation: The Theory of Rational Discourse as Theory of Legal Justification. Oxford: Oxford University Press.

Bonnin JE (2014a) To speak with the other's voice: Reducing asymmetry and social distance in mental health care admission interviews. Journal of Multicultural Discourses 9: 149-171.

Bonnin JE (2014b) Treating without diagnosis: Psychoanalysis in medical settings in Argentina. Communication and Medicine 11(1): 15-26.

Broer T, Nieboer A and Bal R (2014) Mutual powerlessness in client participation practices in mental health care. Health Expectations 17(2): 208-219.

Casstevens WJ (2010) Social work education on mental health: Postmodern discourse and the medical model. Journal of Teaching in Social Work 30(4): 385-398.

Collantes Fraile C (2005) Derecho y traducción: Nuevos rumbos comunes [Law and translation: New common directions]. Hermeneus 7: 21-38.

Cox P (2009) 'Connectivity': Seeking conditions and connections for radical discourses and praxes in health, mental health and social work. Social Theory \& Health 7(2): 170-186.

De Miguel E (2000) El texto jurídico-administrativo: Análisis de una orden ministerial [The legaladministrative text: Analysis of a ministerial order]. Círculo de Lingüística Aplicada a la Comunicación, 4 November. Available at: http://www.ucm.es/info/circulo/no4/index.htm (accessed 2 July 2015).

De Pinho LB, Kantorski LP and Hernández AMB (2009) Critical discourse analysis: New possibilities for scientific research in the mental health area. Revista Latino-Americana de Enfermagem 17(1): 126-132.

Donnelly TT and Long BC (2003) Stress discourse and western biomedical ideology: Rewriting stress. Issues in Mental Health Nursing 24(4): 397-408.

Essen C, Freshwater D and Cahill J (2015) Towards an understanding of the dynamic sociomaterial embodiment of interprofessional collaboration. Nursing Inquiry 22(3): 210-220.

Fairclough N (1992) Discourse and Social Change. Cambridge: Polity Press in association with Blackwell Publishing. 
Firbas J (1966) On defining the theme in functional sentence analysis. Travaux Linguistiques de Prague 1: 267-280.

García da Silva DE (2007) Critical discourse analysis and the functional bases of language. In: Barbara L and Sardinha TB (eds) Proceedings of the 33rd International Systemic Functional Congress. São Paulo: Pontifical Catholic University of São Paulo, pp. 932-949.

González Salgado JA (2009) El lenguaje jurídico del siglo XXI [The XXI Century's legal language]. Diario La Ley 7209: 1-6.

Guba EG Lincoln YS (1998) Competing paradigms in qualitative research. In: Denzin NK and Lincoln YS (eds) The Landscape of Qualitative Research: Theories and Issues. Thousand Oaks, CA: SAGE, pp. 195-220.

Halliday M and Matthiessen C (2004) An Introduction to Functional Grammar, 3rd edn. London: Edward Arnold.

Hausner H, Hajak G and Spiessl H (2007) Does sociotherapy lose importance in scientific discourse? Psychiatrische Praxis 34(8): 395-399.

Jhangiani SJ and Vadeboncoeur JA (2010) Health care as usual: The insertion of positive psychology in Canadian mental health discourse. Mind, Culture and Activity 17(2): 169-184.

Kaplan N (2004) Nuevos desarrollos en el estudio de la evaluación en el lenguaje: La Teoría de la Valoración [New developments in the study of evaluation in language: Appraisal Theory]. Boletín de Lingüistica 22: 52-78.

Lavandera B (1985) Decir y aludir: Una propuesta metodológica [To say and to allude to: A methodological proposal]. Filología xx 2: 21-31.

Mancini MA (2011) Understanding change in community mental health practices through critical discourse analysis. British Journal of Social Work 41(4): 645-667.

Mancini MA and Rogers R (2007) Narratives of recovery from serious psychiatric disabilities: A critical discourse analysis. Critical Approaches to Discourse Analysis across Disciplines 1(2): 35-50.

Marchese M (2009) Evidencias de (inter)subjetividad en el discurso institucional-estatal. La contribución del análisis del discurso para el pensamiento crítico [Evidences of (inter) subjectivity in institutional-state discourse. The contribution of Discourse Analysis to critical thinking]. Cadernos de Linguagem e Sociedade 10(2): 77-99.

Marchese M (2010) Marcas evaluativas en el discurso estatal sobre sujetos en situación de indigencia. Un estudio de caso a través de la Teoría de la Valoración [Evaluative marks in state discourse about persons in extreme poverty situations. A case study using Appraisal Theory]. Texturas. Estudios Interdisciplinarios sobre el Discurso 9(9-10): 113-132.

Montecino L (ed.) (2010) Discurso, pobreza y exclusión en América Latina [Discourse, poverty and exclusion in Latin America]. Santiago, Chile: Cuarto Propio.

Oxford Dictionary (n.d.) Available at: http://www.oxforddictionaries.com/definition/english/ (accessed 31 July 2015).

Pardo ML (1996) Derecho y Lingüistica. Cómo se juzga con palabras [Law and Linguistics. How judging is done with words], 2nd edn. Buenos Aires, Argentina: Nueva Visión.

Pardo ML (2008) Una metodología para la investigación lingüística del discurso [A methodology for the linguistic research on discourse]. In: Pardo ML (ed.) El discurso sobre la pobreza en América Latina [The discourse about poverty in Latin America]. Santiago, Chile: Frasis, pp. 55-78.

Pardo ML (2010) La teoría de la tonalización y la de valoración: Dos visiones complementarias [The theory of tonalization and the theory of appraisal: Two complementary vis-ions]. Cadernos de Linguagem e Sociedade 11(1): 113-127.

Pardo ML (2011) Teoría y metodología de la investigación lingüística. Método sincrónicodiacrónico de análisis lingüistico de textos [Theory and methodology of linguistic research. 
The synchronic-diachronic method of linguistic analysis of texts]. Buenos Aires, Argentina: Tersites.

Pardo ML and Buscaglia V (2008) Pobreza y salud mental desde el Análisis Crítico del Discurso. El aislamiento social y el deterioro comunicativo y cognitivo [Poverty and mental health from Critical Discourse Analysis. Social isolation and communicative and cognitive deterioration]. Discurso \& Sociedad 2(2): 357-393.

Pardo Abril N (2007) Cómo hacer Análisis Crítico del Discurso. Una perspectiva Latinoamericana [How to do Critical Discourse Analysis. A Latin American perspective]. Santiago, Chile: Frasis.

Paterson B and Stark C (2001) Social policy and mental illness in England in the 1990s: Violence, moral panic and critical discourse. Journal of Psychiatric and Mental Health Nursing 8(3): 257-267.

Petersen I (1998) Comprehensive integrated primary mental health care in South Africa: The need for a shift in the discourse of care. South African Journal of Psychology 28(4): 196-203.

Pinho MA (2009) Saúde mental, mudanca social e discurso bioético: Uma face da desinstitucionalizacão revelada em uma notícia de jornal [Mental health, social change and bioethical discourse: A view of deinstitutionalization revealed in a newspaper]. Physis 19(3): 817-828.

Raiter A (1999) Lingüistica y Política [Linguistics and Politics]. Buenos Aires, Argentina: Biblos Publishing.

Real Academia Española (2001) Diccionario de la lengua española, 22a ed. Available at: www.rae. es (accessed 2 July 2015).

Resende V and Ramalho V (2006) Análise de discurso crítica [Critical Discourse Analysis]. São Paulo: Contexto.

Ross A (1959) On Law and Justice. Berkeley, CA: University of California Press.

Van Dijk T (1993) Principles of critical discourse analysis. Discourse \& Society 4(2): 249-283.

White P (1999) Un recorrido por la Teoría de la Valoración. Available at: http://www.grammatics. com/appraisal/spanish_tr/spanishtranslation-appraisaloutline.pdf (accessed 11 November 2016).

Wodak R (2000) ¿La Sociolingüística necesita una Teoría Social? Nuevas perspectivas en Análisis Crítico del Discurso [Sociolinguistics: Does it need a social theory? New perspectives in Critical Discourse Analysis]. Revista Iberoamericana de Discurso y Sociedad 2(3): 123-147. Wodak R (2003) El enfoque histórico del discurso [The discourse-historical approach]. In: Wodak R and Meyer M (eds) Métodos de Análisis Crítico del Discurso [Methods of Critical Discourse Analysis]. Barcelona: Editorial Gedisa, pp. 101-142.

\section{Author biographies}

Mariana Marchese graduated as a Doctor of Linguistics at the University of Buenos Aires, having previously received a Licentiate of Arts as well as a Secondary and Higher Education Teacher's degree from the same institution. She works as an assistant professor at the Philosophy and Arts School and a researcher with the National Council for Scientific and Technological Research of Argentina. Dr Marchese taught law-making techniques and administrative writing at the Buenos Aires City Hall and Legislature and was part of the team charged with producing the Handbook of Law-Making Techniques by the Argentine Institute for Standardisation and Accreditation. She is a member of the Latin American Critical Discourse Analysis Network.

Claudia Celerier graduated as a Doctor in Law at the University of Buenos Aires. She is Judge of the First Instance Civil and Commercial Court No. 8 of the Quilmes Judicial District, Buenos Aires Province, Argentina. Her career started in 1994 at the Civil and Commercial Court of Appeals, where she worked as a reporting clerk and then as a legal assistant. From 2002 to 2010, she was secretary of the tribunal's Second Division. She was assistant professor of contract law at the School of Law and Social Science of the University of Buenos Aires. 